\title{
Time Series Analysis on Agricultural Commodity Prices
}

\author{
K. Sathya ${ }^{1} \&$ R. Karthiban ${ }^{2}$ \\ ${ }^{1,2}$ Department of Computer Science and Engineering, Sri Shakthi Institute of Engineering and Technology, Coimbatore, India. \\ DOI: http://doi.org/10.38177/ajast.2021.5205
}

Copyright: $\odot 2021$ K.Sathya \& R.Karthiban. This is an open access article distributed under the terms of the Creative Commons Attribution License, which permits unrestricted use, distribution, and reproduction in any medium, provided the original author and source are credited.

Agriculture is a main source of production of food crops. The food crops are produced, processed, promoted and distributed widely. Productions of these crops are diseased by pant pathogens and several environmental conditions. The market price of the crops decides their supplies and demand. Due to the climatic variations and natural calamities the price of the crop has varied to a larger extend. Statistical time series analyses are performed to analyse trends and identify relevant seasons of different agricultural commodity price for different APMCs of Maharashtra. Time-series Analysis is performed for analysing and visualizing the price fluctuation in each relevant season.

Keywords: MSP, APMC, Accuracy, Prediction.

\section{Introduction}

Agriculture is at the focal point of Indian economy and any significant change in the area prompts a multiplier impact on the whole economy. With around 17\% commitment to the Gross Domestic Product (GDP), it gives work to over half of the labor force( i.e.50\%). The biggest businesses of the nation like sugar,textiles, food handling and so forth are reliant on horticulture and the associated administrations for their crude materials. The significant harvests filled in India incorporate paddy, wheat, beats , consumable oil and cultivation. Alongside this poultry, fishery and creature farming are other major unified administrations. Yet, in spite of the powerful interest, alluring freedoms and strategy support, the area experiences excessive cost instability, low pay among ranchers, slanted MSP rates and absence of credit offices. Subsequently there is a requirement for a drawn out methodology to evaluate request and supply and to figure costs for crops. Being a grain driven agribusiness, the costs of paddy, wheat and grains are of the most significance. Costs of vegetables like potato, tomato, onion additionally should be firmly observed as they sway the food swelling rates in the country. Also the costs of 24 items under the MSP system including 8 oil seeds , crude cotton, crude jute and copra are essential in choosing least help costs just as choosing obtainment costs for the Public Distribution System(PDS). Subsequently farming costs straightforwardly sway the pay of makers and the food security of the country. These time series data related with agrarian costs can be utilized for forecasting present moment and long haul value gauges. It can assist with distinguishing examples and occasional varieties in costs particularly as for creation during kharif, rabi and zaid seasons. Estimating of farming costs are additionally significant for deciding sponsorship rates, least help costs, send out costs etc.Thus observing and controlling horticultural value unpredictability and preplanning strategies to moderate any unfavorable circumstances. Time arrangement of harvest costs can likewise assist with comprehension, decipher and clarify cases of monetary emergency in the farming area. Mediation investigation of such time arrangement can likewise give us experiences into understanding the effect of unexpected value changes over different areas and generally economy. In addition farming value estimates are fundamental in deciding dangers in agri-product prospects and choices exchanging markets. 


\section{Objective}

The purpose of this project is identify relevant seasons of different agricultural commodities. It furthermore analyzes price fluctuations and flags the ones with most fluctuation in relevant months of the season.

\section{Boxplot Agorithm}

A boxplot is a normalized method of showing the conveyance of information dependent on a five number outline ("least", first quartile (Q1), middle, third quartile (Q3), and "greatest"). It can enlighten you regarding your exceptions and what their values are. It can likewise advise you if your information is balanced, how firmly data is assembled, and if and how data is skewed

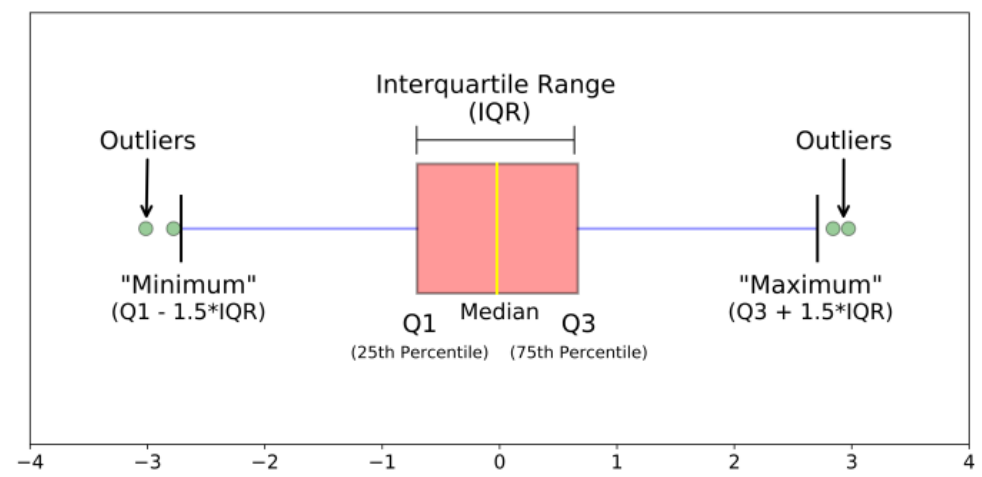

In descriptive statistics, a box plot or boxplot is a method for graphically depicting groups of numerical data through their quartiles. Box plots may also have lines extending vertically from the boxes (whiskers) indicating variability outside the upper and lower quartiles, hence the terms box-and-whisker plot and box-and-whisker diagram.

\section{Results and Discussion}

(1) Testing and filtering outliers from the data. (2) Understanding price fluctuations accounting the seasonal effect: (a) Detecting seasonality type (multiplicative or additive) for each cluster of APMC and commodities, (b) De-seasonalising prices for each commodity and APMC according to the detected seasonality type. (3) Comparing prices in APMC with MSP(Minimum Support Price)- raw and deseasonalised. (4) Flagging set of APMC and commodities with highest price fluctuation across different commodities in each relevant season, and year.

\section{Dataset can be shortly viewed as}

\begin{tabular}{|lrlrrr|}
\hline & commodity & year & Type & msprice & msp_filter \\
\hline 0 & PADDY-UNHUSKED & 2012 & Kharif Crops & 1250.0 & 1 \\
1 & RICE(PADDY-HUS) & 2012 & Kharif Crops & 1280.0 & 1 \\
2 & Jowar_Hybrid & 2012 & Kharif Crops & 1500.0 & 1 \\
3 & SORGUM(JAWAR) & 2012 & Kharif Crops & 1520.0 & 1 \\
4 & BAJRI & 2012 & Kharif Crops & 1175.0 & 1 \\
5 & MAIZE & 2012 & Kharif Crops & 1175.0 & 1 \\
6 & Ragi_Maldandi & 2012 & Kharif Crops & 1500.0 & 1 \\
7 & PIGEON PEA(TUR) & 2012 & Kharif Crops & 3850.0 & 1 \\
8 & SPILT GERRN GRAM & 2012 & Kharif Crops & 4400.0 & 1 \\
9 & SPLIT BLACK GRAM & 2012 & Kharif Crops & 4300.0 & 1 \\
\hline
\end{tabular}




\subsection{Overall Boxplot Visualization}

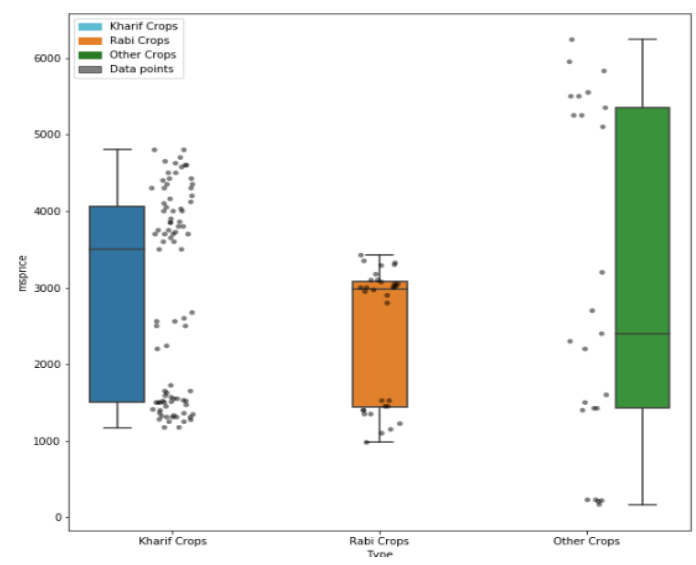

4.2 Finding outlier for individual commodities in a particular type of crop

\section{Kharif Crops}
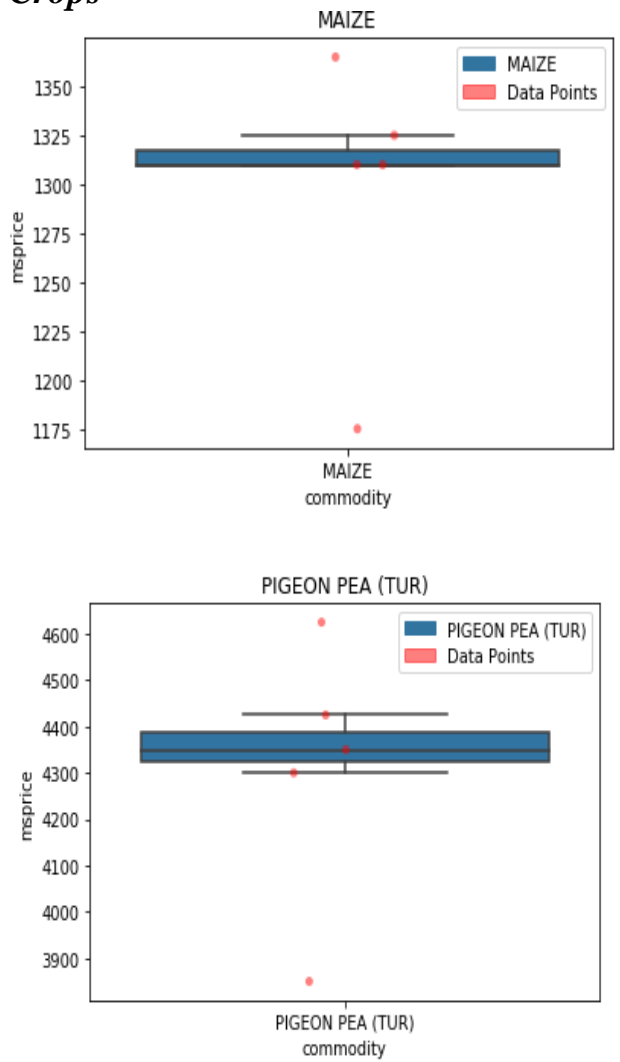
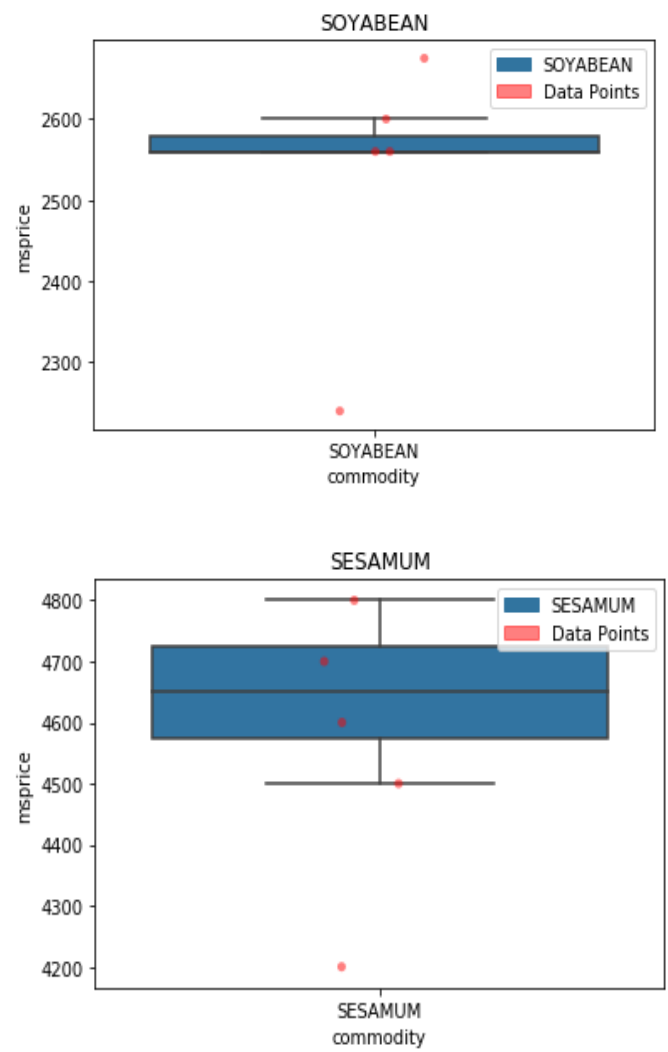

Rabi Crops

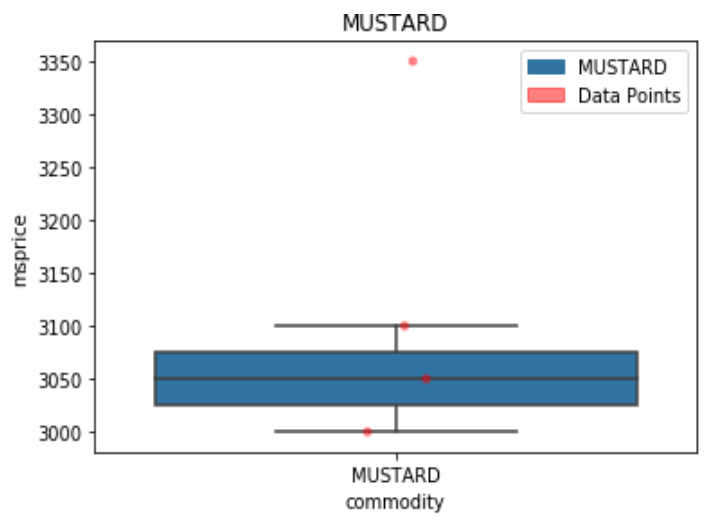




\subsection{Understand price fluctuations accounting the seasonal effect}

Selecting only those APMC Commodities (cluster) which have data points for atleast a complete year (time series analysis)

\begin{tabular}{|c|c|c|c|c|c|}
\hline & APMC & Commodity & Year & combination_label & Count \\
\hline 0 & Aamgaon & paddy-unhusked & 2015 & Aamgaon:paddy-unhusked & 12 \\
\hline 1 & Akhadabalapur & soybean & 2015 & Akhadabalapur.soybean & 12 \\
\hline 2 & Akluj & bitter gourd & 2015 & Akluj:bitter gourd & 12 \\
\hline 3 & Akluj & brinjal & 2015 & Akluj:brinjal & 12 \\
\hline 4 & Akluj & cabbage & 2015 & Akluj:cabbage & 12 \\
\hline 5 & Akluj & chikoo & 2015 & Akluj:chikoo & 12 \\
\hline 6 & Akluj & chillies(red) & 2015 & Akluj:chilles(red) & 12 \\
\hline 7 & Akluj & garlic & 2015 & Akluj:garlic & 12 \\
\hline 8 & Akluj & ladies finger & 2015 & Akluj]:ladies finger & 12 \\
\hline 9 & Akluj & maize & 2015 & Akluj:maize & 12 \\
\hline
\end{tabular}

\subsection{Detect seasonality type (multiplicative or additive) for each cluster of APMC and commodities}

A function that checks the seasonality type and deseasonalizes the prices if passed 'True' as a second parameter

\begin{tabular}{|rrr|}
\hline & Commodity & Seasonality Type \\
\hline 375 & Mumbai:split gram & Multiplicative \\
376 & Mumbai:split lentil & Multiplicative \\
377 & Mumbai:spilt gerrn gram & Multiplicative \\
378 & Mumbai:spilt pigeon pea & Additive \\
379 & Mumbai:split black gram & Multiplicative \\
380 & Mumbai:green peas (dry) & Multiplicative \\
381 & Mumbai:fennel & Additive \\
382 & Mumbai:coconut & Multiplicative \\
\hline
\end{tabular}

\subsection{Compare prices in APMC/Mandi with MSP (Minimum Support Price)- raw and deseasonalised}

A Function which accepts apmc and commodity and prints a comparison line plot

If no such match found within our data due to:

\# 1. Insufficient MSP data

\# 2. Invalid apmc,commodity cluster

\# 3. Apmc, commodity group which has already been filtered out during pre processing

\subsection{Enter the cluster of APMC, Commodity you want to compare}

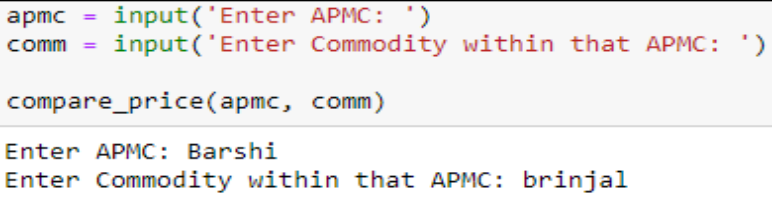




\section{AJAST}

Asian Journal of Applied Science and Technology (AJAST)

Volume 5, Issue 2, Pages 36-41, April-June 2021

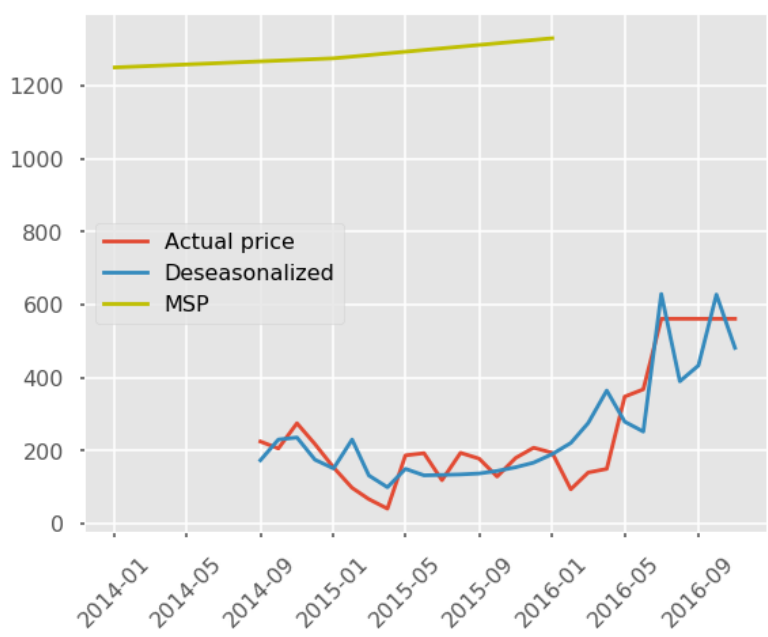

\section{Conclusion}

Crop Price Prediction helps the farmer to timely delivery of food items. Here we used some pre-processing techniques and finally plotted MSP, actual and de-seasonalized prices of the crop. Outlier Detection through Inter-quartile ranges, Statistical Decomposition of Time-series data, Data Visualization are performed for the different APMCs of Maharashtra.

\section{Declarations}

\section{Source of Funding}

This research did not receive any specific grant from funding agencies in the public, commercial, or not-for-profit sectors.

\section{Competing Interests Statement}

The authors declare no competing financial, professional and personal interests.

\section{Consent to participate}

Not Applicable

\section{Consent for publication}

We declare that we consented for the publication of this research work.

\section{Availability of data and material}

Authors are willing to share data and material according to the relevant needs.

\section{Author's contribution}

All authors participated in overseeing laboratory work, data analysis, and manuscript writing and review.

\section{References}

1. Anil Kumar, R. A., Yeledhalli, S. L., Patil, Ch. Patil and K. Choudry. 2012. Market Arrivals and Prices Behaviour of Wheat in Karnataka. Int. J. Agr. Stat. Sci., 8(1): 313-318. 
2. Anonymous, 2008. Maize Statistical Reports. As per Web Information, www.Indiancommodity .com/statistics/maizestat.htm.

3. Ansari, M. I. and Ahmed, S. M. 2001. Time Series Analysis of Tea Prices: An Application of ARIMA Modeling and Co-Integration Analysis. Ind. Econ. J., 48(3): 49-54.

4. Anupama, J., Singh, R. P. and Kumar, R. 2005. Technical Efficiency in Maize Production in Madhya Pradesh: Estimation and Implications. Agr. Econ. Res. Rev., 18(1): 305-315.

5. Bogahawatte, C. 1998. Seasonal Variations in Retail and Wholesale Prices of Rice in Colombo on markets, Srilanka. Ind. J. Agr. Mark., 43(2): 139- 147.

6. Farjam, A., Omid, M., Akram, A. and Fazel, Niari. Z. 2014. A Neural Network Based Modeling and Sensitivity Analysis of Energy Inputs for Predicting Seed and Grain Corn Yields J. Agr. Sci. Tech., 16: 767-778.

7. Gupta, G. S. 1993. ARIMA Model for Forecasts on Tea Production in India. Ind. Econ. J., 41(2): 88-110.

8. Gujarati, N. and Damodar, 2003. Basic Econometric. McGraw-Hill, New Delhi. 9. Makridakis, S. and Hibbon, M.197.

9. Accuracy of Forecasting: An Empirical Investigation. J. Roy. Stat. Soci. Series A (General), 142( 2): 97-145.

10. Marie Steen., G. 1999. Forecasting Prices at the Dutch Flower Auctions. J. Agr. Econ., 50(2): 258 - 268.

11. Saeed, N., Saeed, A., Zakria, M. and Bajwa, M, T. 2000. Forecasting of Wheat Production in Pakistan using ARIMA Models. Int. J. Agr. Bio., 2(4): 352- 353.

12. Samarasinghe, S. 2007. Neural Networks for Applied Sciences and Engineering: From Fundamentals to Complex Pattern Recognition. Auerbach, Boca Raton, FL.

13. Safa. M., Samarasinghe, S. and Nejat, M. 2015. Prediction of Wheat Production Using Artificial Neural Networks and Investigating Indirect Factors Affecting It: Case Study in Canterbury Province, New Zealand. J. Agr. Sci. Tech., 17: 791-803.

14. Singh, R. P., Kumar R. and Singh, N. P. 2003. Transformation of the Indian Maize EconomyDifferent Perspectives. Division of Agricultural Economic, IARI, New Delhi, Technical Bulletin, PP: 1-28.

15. Soltani. A., Bakker M. M., Veldkamp A. and Stoorvogel, J. J. 2016. Comparison of Three Modelling Approaches to Simulate Regional Crop Yield: A Case Study of Winter Wheat Yield in Western Germany. J. Agr. Sci. Tech., 18: 191-206. 